\title{
Rearing Vanaraja Chicken as Backyard Poultry-A Promising Tool towards Women Empowerment
}

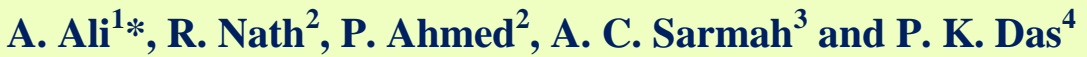 \\ ${ }^{1}$ Department of Veterinary Microbiology, Krishi Vigyan Kendra, \\ Assam Agricultural University, Nalbari, Assam, India \\ ${ }^{2}$ Department of Entomology, SCS College of Agriculture, Assam Agricultural \\ University, Assam, India \\ ${ }^{3}$ Department of Agronomy, SCS College of Agriculture and Department of Soil Science, \\ RARS, Nagaon, Assam Agricultural University, Assam, India \\ ${ }^{4}$ Department of Agricultural Extension Education, KVK, Nalbari, \\ Assam Agricultural University, Assam, India \\ *Corresponding author
}

A B S T R A C T

\begin{tabular}{|l|}
\hline Ke y w o r d s \\
Vanaraja, Semi- \\
intensive, Backyard, \\
indigenous chicken, \\
B:C, Traditional \\
system
\end{tabular}

\begin{abstract}
Economic independency is a key factor for social and cultural empowerment of women. Rearing small scale Vanaraja chicken can be promising for nutritional security and subsidiary income. Rearing indigenous chickens traditionally in Assam faces inherent constraints like low production, high mortalities hindering lucrative return. Realizing needs and to avert aberrant practices demonstrations on raising Vanaraja chickens in semiintensive system ( 30 chicks to each of 40 farmers) were conducted in farmers' backyards. During brooding, limited concentrate feeding was done for 2 weeks. Thereafter, chicks were allowed to scavenge in backyards. Kitchen-wastes, grains and mineral mixtures were supplemented for nutritional needs. Chickens were marketed upon attaining body weight of $\geq 1 \mathrm{~kg}$ (@Rs. 180/Kg). Layers were reared for 1.5 years (162 eggs/annum), thereafter, sold as cull/spent birds. Disease incidences (no major disease outbreak), mortality rates (3\%) were recorded. B:C for Vanaraja and local chickens raised in traditional system were 4.8 and 2.1 respectively.
\end{abstract}

\section{Introduction}

The population of Tinsukia district of Assam, India is predominantly tribal in nature, dietary pattern is non-vegetarian hence there is always a rising demand for meat and egg in the region. Rural tribal people of North-
Eastern Region of India including Sikkim have been practicing traditional backyard poultry farming as an option for their livelihood (Singh et al., 2018). However, the production in the region is poor due to traditional method of rearing livestock and poultry. Therefore, Vanaraja poultry breed 
with high production potential has been introduced and popularized as a source of sustainable livelihood for rural resource poor farm women facilitating their economic empowerment.

\section{Materials and Methods}

Performance evaluation of Vanaraja chicken in backyard system was conducted in Tinsukia district of Assam, India by KVK, Tinsukia. Each of 40 farm women/youths were provided with 30 Vanaraja chicks (3 days old) developed by ICAR directorate of Poultry research, procured from Poultry Division (AICRP), College of Veterinary Science, Khanapara, Assam Agriculture University, Khanapara, Guwahati. All the selected producer women/youths were trained adequately on brooding, feeding, healthcare and other management and hands on method demonstrations were given on vaccination practices to few farmers of the area/SHGs. Chicks were fed with commercial prestarter feed for first 2 weeks. Thereafter, the birds were gradually allowed to scavenge in the backyard, lawns, house attached backyard tea gardens at daytime and sheltered in sheds made of locally available materials at night. The birds were supplemented with cocktail of broken rice, paddy grain, ground maize, kitchen wastes, sometimes mineral mixture mixed with feed. During scavenging, the birds had access to grains, insects, earthworms etc. Vaccinations were done against Ranikhet, Gumboro and Fowl pox.

The weekly body weight gain, disease incidences and mortality pattern of chickens were recorded. Age at first egg laying and number of eggs laid in 40 weeks period were also recorded. Economic analysis of income from Vanaraja and Desi birds was calculated based on the number of chickens sold for meat purpose, eggs produced and live weight after 1 year of egg laying.

\section{Results and Discussion}

Vanaraja chickens are accepted by the farmers due to its colour pattern, growth rate, taste of meat and production of more eggs compared to indigenous chicken reared traditionally. The farmers' preference of Vanaraja for meat purpose particularly is due to fast attainment of market age under traditional backyard system of rearing with limited non-commercial feed. The lesser number of local chicks in the present study compared to Vanaraja chicks was due to lack of commercial availability. The mortality rate during and after brooding stage was 3\% and $10 \%$ among Vanaraja and local chicken respectively. The Vanaraja bird is hardy and has better immune competence due to which it is successfully adaptable under backyard farming system (Niranjan et al., 2008a). Majority of the mortality cases were found to be unintentional negligence of farmer and accidental. Deka et al., (2014) found Vanaraja less prone to environmental stress and mortality of Vanaraja and indigenous birds were $4.55 \pm 0.38$ and $4.85 \pm 0.51$ per cent respectively. Antibiotic and deficiency treatments were practiced seldom to the affected birds only as and when needed. Deka et al., (2014) stated that the health management of the birds was mainly through ethno veterinary medicine as only $12 \%$ of the respondents used conventional drugs. They also stated that Ranikhet disease, which was believed to be the main constraint affecting scavenging chickens in India, was not the major cause of mortality in the vaccinated scavenging chicken and the main cause of death was predator. The labour cost was not accounted for, as the woman herself may work for some time for feeding watering of the chickens. Although the construction of poultry shed was accounted for, $41.48 \%$ and $57.87 \%$ of the production cost of first batch of Vanaraja and local chicken respectively, the whole amount was not deducted from one 
batch. Instead, depreciation cost @ 20\% per batch was subtracted from production cost of each batch. The cost of day old chicks was $17.42 \% 42.14 \%$ respectively for Vanaraja and local chicken. The higher cost of chicks of local birds were mainly due to their unavailability peoples reluctance to sell the day old chicks made the owners ask for higher price. The total cost of feed incurred was $42.14 \%$ and $29.4 \%$ respectively for Vanaraja and local chicken (Table 1).

However, Pathak and Nath (2013) reported that the feed cost alone contributed $90.95 \%$ of the total cost of production in backyard poultry farming in Sikkim which may be due to the inclusion of feed cost for entire duration of 18 months which is not the case in backyard poultry. The cost of vaccine accounted for only $4.15 \%$ and $5.79 \%$ of the total cost of production for both Vanaraja and local chicken.

However, the tribal farmers generally did not vaccinate local poultry birds. Similarly, cost of medicine and feed supplements shared only $4.15 \%$ and $5.79 \%$ of the total cost of production in both Vanaraja and local chickens. The cost of medication was only $0.81 \%$ of the total cost in backyard poultry in Nigeria (Saha, 2003).

In the present study, the total cost of production up to 3 months of age was found to be higher in Vanaraja (Rs. 4822.00) than its local counterpart (Rs. 3456.00) incurring the cost of production per bird Rs. 152.48 and Rs. 128.00 respectively. This variation was due to low feed intake in local chicken, poor growth and low body weight gain of local chickens as compared to Vanaraja chickens. However, it is not surprising to get such results as Vanaraja chickens are developed for high yielding purpose through careful selection and breeding. In contrast to the present findings about cost of production, Pathak and Nath
(2013) reported higher cost of production per bird as Rs. 729.50 under scientific backyard rearing of high yielding chicken in Sikkim. The age at first egg lay was recorded to be 166 days for Vanaraja and 193 days for Local chickens. Deka et al., (2014) found the age of first lay to be 178 days and 191 days for Vanaraja Local chickens respectively.

This variation in age at first egg lay may be due to nutritional status, day length of seasonal variation, weather condition influencing body activity particularly hormonal, variation in dark and light cycle or possible genetical predisposition. However, Gumpha et al., (2018) reported that, the protein and fat content of the eggs did not vary significantly due to variation in protein content of the diets. In case of income generation from Vanaraja birds, sale of eggs contributed the largest share (42.29 \%) followed by sale of cocks and hens before laying (34.22\%) and sale of spent hens (23.49 $\%$ ) details of which is shown in Table 2.

In case of local poultry it was found that almost equal amount of income was generated by sale of eggs $(34.61 \%)$ followed by sale of cocks and hens before laying (32.69\%) and sale of spent hen (32.69\%). Pathak and Nath (2013) reported that the highest amount of income in backyard poultry farming was derived from sale of eggs $(65.96 \%)$ in Sikkim. The egg production of Vanaraja birds were found to be 162 eggs/bird/annum whereas the local birds produced 42 eggs/bird/annum. Similarly Deka et al., (2014) recorded egg production by Vanaraja birds to178 hen/annum and that of local hens 54 eggs/year.

The body weight of Vanaraja and local chickens recorded in this study were $2.3 \mathrm{~kg}$ and $700 \mathrm{gm}$ at 12 weeks through $3 \mathrm{~kg}$ and $1.19 \mathrm{~kg}$ respectively. However, Deka et al., (2014) recorded body weight of $1.2 \mathrm{~kg}$ at 16 
week and $2 \mathrm{~kg}$ at 24 week for Vanaraja and $500 \mathrm{gm}$ at 16 week and $900 \mathrm{gm}$ at 24 week for local chickens. Bharathy et al., (2019) recorded body weight of Vanaraja birds to be $1112.6 \mathrm{~g}$ fed azolla @15\% of ration. Most of the backyard poultry production comprises rearing of indigenous birds of poor production performances. The potential of indigenous birds in terms of egg production is only 40 to 50 eggs/ bird/ year and meat production is also very less (Islam et al., 2015; Singh et al., 2017). The protein content of Vanaraja meat was estimated to be $25.77 \mathrm{a} \pm 0.95$ which is at par with the protein content native chicken meat (Singh and Pathak, 2017).

Table.1 Average production cost of a unit 30 birds from each of Vanaraja and Local poultry in Tinsukia district of Assam

\begin{tabular}{|c|c|c|c|c|}
\hline Particulars & Vanaraja Chicken & $\begin{array}{l}\text { Amount } \\
(\mathbf{R s .})\end{array}$ & Local Chicken & $\begin{array}{l}\text { Amount } \\
\text { (Rs.) }\end{array}$ \\
\hline \multicolumn{5}{|l|}{ A. Fixed cost } \\
\hline a) Land & Existing & - & Existing & - \\
\hline $\begin{array}{l}\text { b) Poultry shed made of } \\
\text { locally available materials }\end{array}$ & & $\begin{array}{c}2000 \\
(41.48)\end{array}$ & & $\begin{array}{c}2000 \\
(57.87)\end{array}$ \\
\hline c) Equipments & $\begin{array}{l}\text { Existing or local } \\
\text { materials }\end{array}$ & - & $\begin{array}{l}\text { Existing or local } \\
\text { materials }\end{array}$ & - \\
\hline \multicolumn{5}{|l|}{ B. Variable cost } \\
\hline a) Cost of day old chicks & $\begin{array}{l}@ \text { Rs. } 28.00 \text { per } \\
\text { chick x } 30 \text { Nos. }\end{array}$ & $\begin{array}{c}840 \\
(17.42)\end{array}$ & $\begin{array}{l}@ \text { Rs. } 38.00 \text { per } \\
\text { chick x } 30 \text { Nos. }\end{array}$ & $\begin{array}{c}1140 \\
(32.99)\end{array}$ \\
\hline $\begin{array}{l}\text { b) Vanaraja: Cost of } \\
\text { commercial prestarter } \\
\text { feed up to } 14 \text { days of age }\end{array}$ & $\begin{array}{l}@ \text { Rs. } 36.00 \text { per kg x } \\
400 \text { g/chick x } 30 \\
\text { Nos. }\end{array}$ & $\begin{array}{c}432 \\
(8.96)\end{array}$ & $\begin{array}{l}@ 200 \mathrm{~g} / \text { chick x } \\
30 \text { Nos. }\end{array}$ & $\begin{array}{c}216 \\
(6.25)\end{array}$ \\
\hline $\begin{array}{l}\text { c. i) Broken rice, paddy } \\
\text { grain, ground maize, } \\
\text { kitchen wastes }\end{array}$ & @ Rs. 20.00 per kg & $\begin{array}{c}1600 \\
(33.18)\end{array}$ & $\begin{array}{l}\text { c. ii) Broken rice, } \\
\text { paddy grain, } \\
\text { ground maize, } \\
\text { kitchen wastes }\end{array}$ & $\begin{array}{c}800 \\
(23.15)\end{array}$ \\
\hline d) Vaccine & @ Rs.5.00 per chick & $\begin{array}{c}200 \\
(4.15)\end{array}$ & @ Rs.5 per chick & $\begin{array}{c}200 \\
(5.79)\end{array}$ \\
\hline $\begin{array}{l}\text { e) Medicine and feed } \\
\text { supplements }\end{array}$ & @ Rs.5.00 per chick & $\begin{array}{c}200 \\
(4.15)\end{array}$ & Nil & $\begin{array}{c}200 \\
(5.79)\end{array}$ \\
\hline f) Labour & - & - & - & - \\
\hline g) Miscellaneous cost & & $\begin{array}{c}750 \\
(15.55)\end{array}$ & & $\begin{array}{c}500 \\
(14.47)\end{array}$ \\
\hline Total variable cost & & 4422 & & 3056 \\
\hline $\begin{array}{l}\text { h) Depreciation of fixed } \\
\text { cost }\end{array}$ & @ 20\% & 400 & @ 20\% & 400 \\
\hline Total cost of production & & 4822 & & 3456 \\
\hline $\begin{array}{l}\text { Cost of production per } \\
\text { bird }\end{array}$ & & 152.48 & & 128.00 \\
\hline
\end{tabular}

Figures in parentheses indicate per cent of total cost of production 
Table. 2 Comparative returns from various components of Vanaraja and local chickens

\begin{tabular}{|c|c|c|c|c|}
\hline Particulars & Vanaraja & $\begin{array}{l}\text { Amount } \\
\text { (Rs.) }\end{array}$ & Local & $\begin{array}{l}\text { Amount } \\
\text { (Rs.) }\end{array}$ \\
\hline $\begin{array}{l}\text { Sale of eggs (10 } \\
\text { Nos. of hens) }\end{array}$ & $\begin{array}{l}\text { Average annual egg } \\
\text { production: } 162 \pm 3.42 \\
\text { eggs/hen, Total egg } \\
\text { production: } 1620 \text { Nos. @ } \\
\text { Rs.6/egg }\end{array}$ & $\begin{array}{l}9720 \\
(42.29)\end{array}$ & $\begin{array}{l}\text { Average annual egg } \\
\text { production: } 42 \pm 4.25 \\
\text { eggs/hen, Total egg } \\
\text { production: } 420 \text { nos. } \\
\text { @ Rs. 6/egg }\end{array}$ & $\begin{array}{l}2520 \\
(34.61)\end{array}$ \\
\hline $\begin{array}{l}\text { Sale of cocks + } \\
\text { hens }\end{array}$ & $\begin{array}{l}19 \text { Nos. of Vanaraja birds } \\
\text { Average weight: } 2.30 \pm 0.24 \\
\text { Kg, Total weight: } 43.7 \mathrm{Kg} \\
@ 180 / \mathrm{Kg}\end{array}$ & $\begin{array}{l}7866 \\
(34.22)\end{array}$ & $\begin{array}{l}17 \text { Nos. of local birds } \\
\text { Average weight: } 0.7 \pm \\
0.28 \mathrm{Kg} \text {, Total } \\
\text { weight: } 11.9 \mathrm{Kg} @ \\
200 / \mathrm{Kg}\end{array}$ & $\begin{array}{l}2380 \\
(32.69)\end{array}$ \\
\hline $\begin{array}{l}\text { Sale of spent } \\
\text { hen }()\end{array}$ & $\begin{array}{l}10 \text { Nos. of Vanaraja hen } \\
\text { Average weight: } 3.00 \pm 0.12 \\
\text { Kg, Total weight: } 30.00 \mathrm{Kg} \\
\text { @ } 180 / \mathrm{Kg}\end{array}$ & $\begin{array}{l}5400 \\
(\mathbf{2 3 . 4 9})\end{array}$ & $\begin{array}{l}10 \text { Nos. of local hen } \\
\text { Average weight: } 1.19 \\
\pm 0.34 \mathrm{Kg} \text {, Total } \\
\text { weight: } 20.30 \mathrm{Kg} @ \\
200 / \mathrm{Kg}\end{array}$ & $\begin{array}{l}2380 \\
(\mathbf{3 2 . 6 9})\end{array}$ \\
\hline $\begin{array}{l}\text { Total gross } \\
\text { income }\end{array}$ & & 22986 & & 7280 \\
\hline Net income & & 18164 & & 3824 \\
\hline $\begin{array}{l}\text { Net income per } \\
\text { bird }\end{array}$ & & 626.34 & & 131.86 \\
\hline $\begin{array}{l}\text { Benefit: cost } \\
\text { ratio }\end{array}$ & & 4.8 & & 2.1 \\
\hline
\end{tabular}

Figures in parentheses indicate per cent of total return

The income from Vanaraja chicken by sale of eggs was much higher than its local counterparts, which was due to production of about (4 times) more numbers of eggs by Vanaraja birds (Uddin et al., 2013). The total gross income in Vanaraja chicken was also more than the local poultry under backyard rearing. Accordingly, the net income from Vanaraja birds was also higher than local poultry. Similar result was also reported by Singh et al., (2019). In the present study the benefit: cost $(\mathrm{B}: \mathrm{C})$ ratio in Vanaraja and local chicken was recorded to be 4.8 and 2.1 respectively. Singh et al., (2019) recorded the benefit-cost (B:C) ratio in Vanaraja and local chicken as 4.41 and 1.57 respectively. The higher benefit: cost ratio in Vanaraja is due to more egg production and attainment of better body weight in the given period of time as compared to local chicken. However, much higher benefit cost ratio (5.57) in native poultry reared was reported in the coastal regions of Bangladesh (Oladunni and Fatuase, 2014). Saha, (2003) reported a much lower benefit: cost $(\mathrm{B}: \mathrm{C})$ ratio of 1.73 in Rhode Island Red chicken rearing in backyard system in North 24 Parganas district of West Bengal.

The benefit cost ratio was 1.73 in scientific backyard poultry farming in Sikkim (Pathak and Nath, 2013) whereas (Niranjan et al., 2008b) reported higher benefit: cost ratio for Vanaraja (2.60) as compared to local poultry 
(2.27) in Assam. The average benefit: cost ratios of layer and broiler farms were 1.15 and 1.10 , respectively under intensive system of management in Bangladesh (Masud and Real, 2013). The higher B:C ratio in case of Vanaraja chicken indicates that Vanaraja rearing is much more profitable in the study areas than local chicken mainly due to more number of eggs and higher body weight at a given age.

Backyard poultry production is a traditional livelihood option where rural women are mostly associated. However, majority of the backyard poultry are indigenous birds with poor production of meat and eggs. The egg production of indigenous birds generally ranges from 40 to 50 eggs/ bird/year and meat production is also very less ranging from 0.5 to $1.5 \mathrm{~kg}$. Therefore, there seems a silverline for developing backyard poultry production with improved varieties of chicken viz., Vanaraja with promising better production of meat and egg and higher income generation. The backyard poultry farming is a kind of sustainable livelihood option, promotes organic farming putting emphasis on use and recycle of locally available (feed) resources. It requires low initial investment; returns high income comparatively within short duration and also ensures animal's natural behavior and welfare. Backyard poultry farming with improved Vanaraja birds carries immense possibility of improving socio-economic status; remove protein deficiency from the society and revolutionizing rural economy through women empowerment.

\section{Acknowledgement}

Due acknowledgement is extended to ICAR, New Delhi; ATARI-Zone-VI, Guwahati and DEE, AAU, Jorhat under which the KVK is functioning where the current work was accomplished under different KVK programmes. Director of Research (Vety),
AAU, also acknowledged for providing Vanaraja chicks.

\section{References}

Bharathy, N., Vasanthakumar, P. and Akila, N. 2019. Growth Performance of Vanaraja Birds Fed Fresh Azolla Incorporated Diets under Intensive Productive System. Int. J. Livest. Res. 9(1): 202-205.

Deka, P., Sarma, M., Nath, P.J., Borgohain, R., Mahanta, J., Deka, B. and Phukon, M. 2014. Production Performance of Vanaraja Bird under Traditional System of Rearing In Assam. Int. J. Livest. Res. 4(2): 81-85.

Gumpha, L.K., Babu, L.K., Kumar, A., Samal, P. and Panda, A.K. 2018. Effect of Low Protein Diets on Egg Quality and Egg Composition of Vanaraja Laying Hens. Int. J. Livest. Res. 8(9): 80-86.

Islam, R., Nath, .P, Bharali, A. and Borah, R. 2015. Analysis of benefit-cost (B:C) ratio of Vanaraja and Local chicken of Assam under backyard system of rearing. J Res. Agri. Anim. Sci. 3(7): 07-10.

Masud, M. and Real, I.I. 2013. Economic benefit of farmers from small-scale broiler and layer farming of Thakurgaon District. Bangladesh Res. Public. J. 8(4): 191-195.

Niranjan, M., Sharma, R.P., Rajkumar, U., Chatterjee, R.N., Reddy, B.L. and Bhattacharya, T.K. 2008b. Livest. Res. Rural Dev. 20.

Niranjan, M., Sharma, R.P., Rajkumar, U., Reddy, B.L.N., Chatterjee, R. and Battacharya T.K. 2008a. Comparative Evaluation of Production Performance in Improved Chicken Varieties for Backyard Farming. Int. J. Poult. Sci. 7(11): 1128-1131.

Oladunni, M. E. and Fatuase, A.I. 2014. 
Economic Analysis of Backyard Poultry Farming in Akoko North West Local Government Area of Ondo State, Nigeria. Glob. J. Biol. Agri. Hlth. Sci. 3(1), 141-147.

Pathak, P.K., and Nath, B.G. 2013. Rural poultry farming with improved breed of backyard chicken. J. World Poult. Res. 3: 24-27.

Saha, D. 2003. Status of rural poultry production in North 24 Parganas district of West Bengal. M.V.Sc. Thesis, Division of Extension Education, IVRI, Izatnagar.

Singh M., Islam R. and Avasthe R.K. 2017. Production performance of Vanaraja Birds under traditional tribal production system of Sikkim Himalayan Region. Int. J. Livest. Res. 7 (7): 153-157.

Singh M., Islam R. and Avasthe R.K. 2018. Factors affecting fertility, hatchability and chick survivability of Vanaraja birds under intensive rearing in subtemperate condition. Indian J. Anim. Sci. 88(3): 331-334.

Singh, M., Islam, R. and Avasthe, K. 2019. Socioeconomic Impact of Vanaraja Backyard Poultry Farming in Sikkim Himalayas. Int. J. Livest. Res. 9(3); 243-248.

DOIhttp://dx.doi.org/10.5455/ijlr.2018102 9045005

Singh, V.P., and Pathak, V. 2017. PhysicoChemical, Colour and Textural Characteristics of Cobb-400, Vanajara, Aseel and Kadaknath Meat. Int. J. Livest. Res. 7(11); 98-106.

Uddin, M. T., Islam, M.M., Salam, S. and Yasmin, S. 2013. Economics of native poultry rearing in the coastal regions of Bangladesh. Bangladesh J. Anim. Sci. 42(1), 49-56.

\section{How to cite this article:}

Ali, A., R. Nath, P. Ahmed, A. C. Sarmah and Das, P. K. 2020. Rearing Vanaraja Chicken as Backyard Poultry-A Promising Tool towards Women Empowerment. Int.J.Curr.Microbiol.App.Sci. 9(04): 2052-2058. doi: https://doi.org/10.20546/ijcmas.2020.904.245 